УДК 615.8: 636.028

DOI https://doi.org/10.26661/2410-0943-2020-1-04

\title{
Вплив гірудотерапії на репродуктивну функцію лабораторних щурів
}

\author{
Амінов Р. Ф., Фролов О. К., Амінова А. С. \\ ORCID: 0000-0002-8471-1525 \\ Запорізький національний університет, Украйна \\ 91_amin_91@ukr.net
}

\author{
Ключові слова: медична \\ n'явка, фертильність, \\ надсім'яники, сперматозоїди, \\ еякулят.
}

Згідно з останніми даними щодо ветеринарії та сільського господарства одним із важливих чинників зменшення поголів'я у тваринництві $\epsilon$ порушення фертильності тварин. Тому актуальним завданням постає пошук різних методів, які сприятимуть зменшенню безпліддя. Особливу увагу привертають природні фактори, до яких належить і гірудотерапія використання медичних п'явок, біологічно активні речовини яких мають широкий спектр терапевтичних ефектів. Тому метою нашої роботи стало дослідження впливу медичної п'явки на репродуктивну функцію самців щурів, які $є$ загальноприйнятою моделлю в біологічних i доклінічних експериментах. Роботу виконано на 40 нелінійних білих самцях та 40 самицях щурів вагою 250-270 г і віком 6,5-7 місяців та їх новонародженому приплоді. Дослідження проводили на тваринах, які пройшли карантинний режим і не мали зовнішніх проявів захворювання. Для проведення дослідження на самцях було сформовано дві групи тварин - контрольну й експериментальну. Дослідним самцям після їх фіксації робили приставки на куприкову зону медичної п'явки Hirudo verbana iз середньою вагою $1,1 \pm 0,2$ г один раз на тиждень (двічі перед спарюванням і двічі після спарювання з інтактними самицями). Фіксуючі маніпуляції робили також із контрольними самцями, проте без приставок п'явок, після чого їх спарювали 3 інтактними самицями. Дослід iз самцями тривав протягом 1 місяця, із самицями - до народження в них приплоду. У самців досліджували вагу тіла, лімфоїдних органів та надсім'яників, враховували загальну кількість сперматозоїдів i їх фертильність. В інтактних самиць визначали загальну кількість приплоду та їх вагу. Згідно з експериментальними даними в дослідних самців за гірудологічного впливу відбувається збільшення ваги тіла (на $16,8 \%$ ) та лімфоїдних органів (тимус - на $23,0 \%$, селезінка на $11,5 \%)$ порівняно 3 контрольною групою тварин $(\mathrm{p}<0,05)$. Наші експериментальні дані доводять, що гірудологічний вплив також сприяв позитивній стимуляції показників репродуктивної функції самців: збільшувалася вага надсім'яників, кількість сперматозоїдів в еякуляті 3 паралельним зниженням морфологічно дефектних гамет серед них порівняно з інтактними тваринами. Стимуляція репродуктивних ознак у дослідної групи самців сприяла підвищенню фертильності в інтактних до гірудологічного впливу самиць, які народжували більший за кількістю й вагою приплід із майже нульовою їх смертністю. 


\title{
Influence of hirudotherapy on the reproductive function of laboratory rats
}

\author{
Aminov R. F., Frolov A. K., Aminova A. S. \\ Zaporizhzhia National University, Ukraine
}

Key words: medicinal leech, fertility, epididymis, sperm, ejaculate.

\begin{abstract}
One of the important factors in reducing livestock is the fertility dysfunction. The relevant problem is to find effective and natural methods to reduce infertility. Particular attention is drawn to hirudotherapy to use biologically active substances of medical leeches in therapeutic practice. Our study is focused on the effect of medical leeches on the reproductive function of male rats, which are a common model in biological and preclinical experiments. The work was performed on 40 nonlinear white male rats weighing 250-270 g, aged 6,5-7 months and their newborn offspring. The study used animals that were quarantined and had no external manifestations of the disease. Two groups of animals were formed for the study - control and experimental. After locking the animals, Hirudo verbana with an average weight of $1,1 \pm 0,2 \mathrm{~g}$ were attached to the coccygeal zone, once a week (twice before mating and twice after). Locking manipulations were also performed with control males, but without leech attachments, after which they were mated with intact females. The experiment with males lasted for 1 month, and females before birth in their offspring. Males were tested for body weight, lymphoids, and over the testicles, total sperm count and fertility, fertility, and total offspring. According to the experimental data, the significant weight gain (by 16,8\%) and lymphoid organs (thymus by $23,0 \%$ and spleen by $11,5 \%$ ) of the experimental animals compared to the control group of animals was observed under hirudological effect. Our experimental data show that hirudological influence also contributed to the positive stimulation of male reproductive function: increased weight over the testes, the quantity of sperm in the ejaculate with a parallel decrease in morphologically defective gametes among them compared to intact animals. Stimulation of reproductive traits in the experimental group of males, contributed to increased fertility in intact to hirudological influence of females, who gave birth to a larger number and weight of offspring, with almost zero mortality.
\end{abstract}

\section{Вступ}

Сучасна медико-біологічна спільнота констатує, що забруднення навколишнього середовища та стреси різної етіології сприяють зростанню порушень репродуктивної функції ${ }^{1-6}$. У XXI столітті демографічна карта України змінилася в бік смертності порівняно з рівнем народжуваності, i 3 кожним роком ця тенденція збільшується. Одна 3 основних причин цих змін - порушення репродуктивної функції як жінок, так і чоловіків ${ }^{7-14}$. Безпліддя є однією з головних проблем світового рівня в багатьох галузях, зокрема медицині, ветеринарії та сільському господарстві ${ }^{15,16}$. В Україні $\epsilon$ близько 1,5 мільйона безплідних через порушення репродуктивної функції пар ${ }^{17,18}$. Також зростає безпліддя у ветеринарії та сільськогосподарському тваринництві.

Аналіз останніх наукових робіт показав, що більшість досліджень присвячені жіночому безпліддю ${ }^{19-22}$, тоді як вивченню чоловічого приділяється мало уваги ${ }^{5,23,24}$. Однак у більшості випадків саме чоловіче безпліддя стає причиною проблем iз зачаттям. Чоловіче безпліддя становить до 50\% від загальної кількості безплідних шлюбів ${ }^{25,26}$. За чоловічого безпліддя основними патологічними станами репродуктивної функції $є$ порушення фертильності та загальної кількості сперматозоїдів в еякуляті, про що свідчить періодичний перегляд норм спермограми в останні десятиліття Всесвітньою організацією охорони здоров'я, яка вказує на відповідне їх зниження ${ }^{27}$.

Аналіз проблеми безпліддя у ветеринарії та сільському господарстві виявив, що воно є одним 3 основних негативних факторів, які знижують поголів'я, а тому й економічну ефективність тваринництва ${ }^{32}$. Тому актуальним для дослідників стає пошук різних методів, які сприятимуть зменшенню цієї недуги. Особливу увагу зараз привертають різні натуротерапевтичні методи впливу, до яких належить і гірудотерапія - використання медичних п'явок. Ї̈̈ біологічно активні речовини (далі - БАР) мають широкий спектр терапевтичних ефектів: здійснення регуляції гемостазу та тонусу судин, протизапальну, реге- 
неративну, нейротропну, бактеріостатичну, імуномодулюючу дію ${ }^{28-31}$. О.К. Фролов та співавтори (2010) довели, що після гірудологічного впливу в кіз підвищується вага тіла, збільшується молочність без ускладнення маститом, а в репродуктивний період спостерігається 100\% запліднення, народження двійнят зі збільшеною масою порівняно 3 контрольною групою ${ }^{32}$. Інші дослідники експериментально підтвердили, що за умови застосування гірудотерапії як основного методу в жінок пришвидшується виліковування певних захворювань, а саме ендометріозу, гіпоплазії матки, полікістозу яєчників, які можуть викликати безпліддя в жінок ${ }^{33}$. Через такий широкий спектр дії БАР медичних п'явок та світову проблему безпліддя, особливо чоловічого, постала необхідність дослідити їх вплив на репродуктивну функцію самців щурів та опосередковано через них на фертильність інтактних самиць.

\section{Матеріали та методи}

Роботу було виконано на 40 нелінійних білих самцях та 40 самицях щурів вагою 250-270 г i віком 6,5-7 місяців. Для дослідження використовували тварин, які пройшли карантинний режим і не мали зовнішніх проявів захворювання. Маніпуляція з тваринами проводилася 3 дотриманням регламентованих норм та правил поводження з лабораторними тваринами, а саме принципів біоетики, законодавчих норм та вимог Свропейської конвенції про захист хребетних тварин, що використовуються для досліджень та наукових цілей, і Закону України «Про захист тварин від жорстокого поводження». Для проведення дослідження на самцях було сформовано дві групи тварин контрольну й експериментальну. Після фіксації тварин у розробленому нами фіксаторі ${ }^{34}$ самцям робили приставки на куприкову ділянку медичної п'явки Hirudo verbana із середньою вагою 1,1 $1 \pm 0,2$ г один раз на тиждень (двічі перед спарюванням 3 інтактними самицями та двічі після). Час від приставки до відпадання п'явок тривав 20-30 хв. Фіксуючі маніпуляції робили також із контрольними самцями, проте без приставок п'явок. Після цього їх також спарювали 3 інтактними самицями 3 умовами коїтусу, як і в дослідній групі. Самців виводили 3 досліду через місяць спостережень шляхом дислокації шийних хребців із наступною декапітацією. Фізіологічний стан тварин вивчали за морфометричними показниками, зокрема досліджували вагу тіла та основних лімфоїдних органів (селезінку і тимус). Репродуктивну функцію самців аналізували в такій послідовності: визначали масу надсім'яників, потім їх розрізали вздовж та вимивали 3 них еякулят у 5 мл $5 \%$-го розчину глюкози, зробленому на фізіологічному розчині, попередньо нагрітому до температури тіла тварини ${ }^{35,36}$. В отриманій суспензії еякуляту рахували загальну кількість сперматозоїдів за допомогою камери Горяєва. Еякулят до визначення фертильності перебував у термостаті за температури $38^{\circ} \mathrm{C}$. Визначення фертильності сперматозоїдів проводили в камері Горяєва (до фертильних відносили сперматозоїди, які в камері переміщувалися у просторі чи здійснювали рухи на одному місці). Морфологічні дослідження сперматозоїдів проводили на мазках, які робили з нерозведеного еякуляту, який після фіксації в 96\%-му спирті фарбували $15 \%$-им розчином Романовського-Гімзи 30 хв. Приплід від дослідної та контрольної груп самців отримували після спарювання з інтактними до гірудологічного впливу самицями шляхом аналізу при їх народженні - визначення смертності та загальної ваги. Самиць до самців підсаджували після виконання другої приставки п'явок і тримали із самцями до вагітності самиць упродовж 2 тижнів. Дослідження проводилися в один і той же сезон і час. Статистичну обробку отриманих даних здійснювали за допомогою параметричних статистичних методів (t-критерій Стьюдента), попередньо перевіривши вибірку на нормальність розподілу зі значеннями в таблицях, поданих $\mathrm{y}$ формі $\mathrm{X} \pm \mathrm{SE}$, де $\mathrm{X}$ - середнє значення показника 3 вибірки, SE - стандартна помилка середнього, 3 пакетом додатків Microsoft Excel Excepts та PAST. Відмінності вважалися надійними на рівні значущості $\mathrm{p}<0,05$.

\section{Результати}

Під час аналізу ваги тіла та лімфоїдних органів у дослідних самців зареєстроване збільшення цих показників порівняно 3 контролем $(\mathrm{p}<0,05)$ (див. табл. 1).

Дослідження експериментальної групи тварин, яким робилися приставки на куприкову ділянку медичної п'явки (рис. 1), виявило значне збільшення ваги надсім'яників порівняно з контролем $(\mathrm{p}<0,05)$ (див. табл. 2).

Дослідження еякуляту з надсім'яників дослідної групи самців показало різке збільшення загальної кількості сперматозоїдів в 1 мкл еякуляту в експериментальної групи тварин (майже

Таблиця 1 - Вага тіла та лімфоїдних органів після гірудологічного впливу

\begin{tabular}{|c|c|c|c|}
\hline Група тварин & Вага тіла, г & Вага тимусу, мг & Вага селезінки, мг \\
\hline Самці контроль, $\mathrm{n}=20$ & $246,2 \pm 11,2$ & $209,6 \pm 10,4$ & $865,8 \pm 13,1$ \\
\hline Самці експеримент, $\mathrm{n}=20$ & $296,1 \pm 12,1^{*}$ & $272,1 \pm 11,1^{*}$ & $978,1 \pm 12,0^{*}$ \\
\hline
\end{tabular}

Примітка: * - показники, що достовірно відрізняються від контролю $(\mathrm{p} \leq 0,05)$ 
в 2 рази) порівняно 3 контрольною групою $(\mathrm{p}<0,05)$, а показник фертильності - в 4 рази (див. табл. 2 та рис. 2).

Під час морфологічного аналізу в мазку сперматозоїдів в експериментальній групі траплялося набагато менше (у 2 рази) дефектних сперматозоїдів, ніж у контрольній групі (див. табл. 2 та рис. 3).

Під час дослідження приплоду від самців дослідної групи було зареєстровано значне збільшення їх чисельності та загальної маси порівняно 3 контрольною групою $(\mathrm{p}<0,05)$ (див. табл. 3). У дослідній групі народжувалися завжди активні та здорові тварини порівняно 3 контрольною, у якій іноді траплявся частково мертвий приплід під час народження $(\mathrm{p}<0,05)$.

\section{Обговорення}

Згідно 3 експериментальними даними під впливом БАР МП в дослідних самців щурів відбувалося збільшення ваги тіла та лімфоїдних органів (тимусу, селезінки). Ці дані підтвердили наші попередні досліди на самках щурів ${ }^{28-31}$. Так, у дослідної групи самок щурів збільшується маса тіла та дослідні лімфоїдні органи (тимус, селезінка). Причому гістологічні дослідження виявили збільшення основних структур тимусу й селезінки ${ }^{28-31}$. Як уже було зазначено, східна динаміка впливу БАР МП визначалася також у дослідах iз малою рогатою худобою ${ }^{32}$. У всіх зазначених дослідних груп тварин позитивні морфофізіологічні зсуви супроводжувалися адекватними змінами їх репродуктивної функції. Так, у нашому експерименті в дослідної групи самців щурів підвищувалася вага надсім'яників, збільшувалася кількість сперматозоїдів, покращувалися їх морфологічні та фізіологічні властивості. Цей факт ми виявили вперше, у доступній нам літературі ми не зустрічали схожі дані. Під час аналізу морфологічних показників сперматозоїдів у мазках експериментальної групи виявлялася менша кількість морфологічно дефектних сперматозоїдів, що свідчить про позитивний гірудологічний вплив і на морфологію сперматозоїдів. При цьому варто зазначити, що багатьма дослідниками доведено, що морфологічно дефектні сперматозоїди
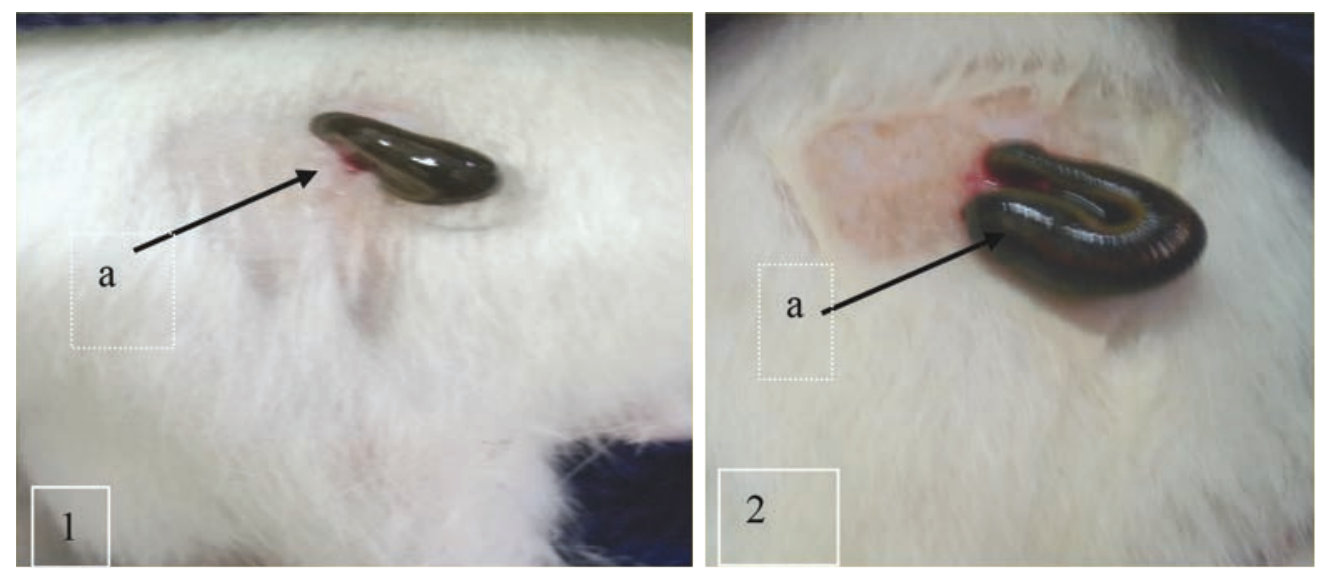

Рис. 1. Приставка медичної п’явки на куприкову ділянку 1, 2: a - Hirudo verbana

Таблиця 2 - Вага надсім’яників та дані спермограми самців після гірудологічного впливу

\begin{tabular}{|c|c|c|c|c|}
\hline Група тварин & $\begin{array}{c}\text { Вага } \\
\text { надсім'яників, мг }\end{array}$ & $\begin{array}{c}\text { Загальна кількість } \\
\text { сперматозоїдів в 1 мкл } \\
\text { 3 5 мл суспензії еякуляту }\end{array}$ & $\begin{array}{c}\text { Фертильність } \\
\text { сперматозоїдів в 1 мкл }\end{array}$ & $\begin{array}{c}\text { Дефектні } \\
\text { сперматозоїди нуспензії еякуляту }\end{array}$ \\
\begin{tabular}{c} 
200 клітин (шт.) \\
\hline Контроль, $\mathrm{n}=20$
\end{tabular} & $511 \pm 23$ & $5750 \pm 287$ & $300 \pm 14$ & $47,0 \pm 4,0$ \\
\hline Експеримент, $\mathrm{n}=20$ & $678 \pm 31,7^{*}$ & $9950 \pm 497 *$ & $1200 \pm 59^{*}$ & $20,0 \pm 3,0^{*}$ \\
\hline
\end{tabular}

Примітка: * - показники, що достовірно відрізняються від контролю $(\mathrm{p} \leq 0,05)$

Таблиця 3 - Середні показники чисельності, загальної ваги та смертності приплоду, отриманого від інтактних самиць, яких спарювали 3 контрольними або експериментальними самцями

\begin{tabular}{|c|c|c|c|c|}
\hline \multirow{2}{*}{\multicolumn{2}{|c|}{ Група тварин }} & \multicolumn{2}{|c|}{ Показники приплоду } & \multirow{2}{*}{$\begin{array}{l}\text { Кількість народжених } \\
\text { мертвих тварин (шт.) }\end{array}$} \\
\hline & & Кількість (шт.) & Загальна вага (г) & \\
\hline \multirow{2}{*}{$\begin{array}{l}\text { Інтактні } \\
\text { самиці }\end{array}$} & Самці контроль, $\mathrm{n}=20$ & $5,3 \pm 1,0$ & $35,3 \pm 7,0$ & $0,9 \pm 0,02$ \\
\hline & Самці експеримент, $\mathrm{n}=20$ & $9,8 \pm 1,4^{*}$ & $68,1 \pm 5,1^{*}$ & $0,0001 \pm 0,00001 *$ \\
\hline
\end{tabular}

Примітка: * - показники, що достовірно відрізняються від контролю $(\mathrm{p} \leq 0,05)$ 

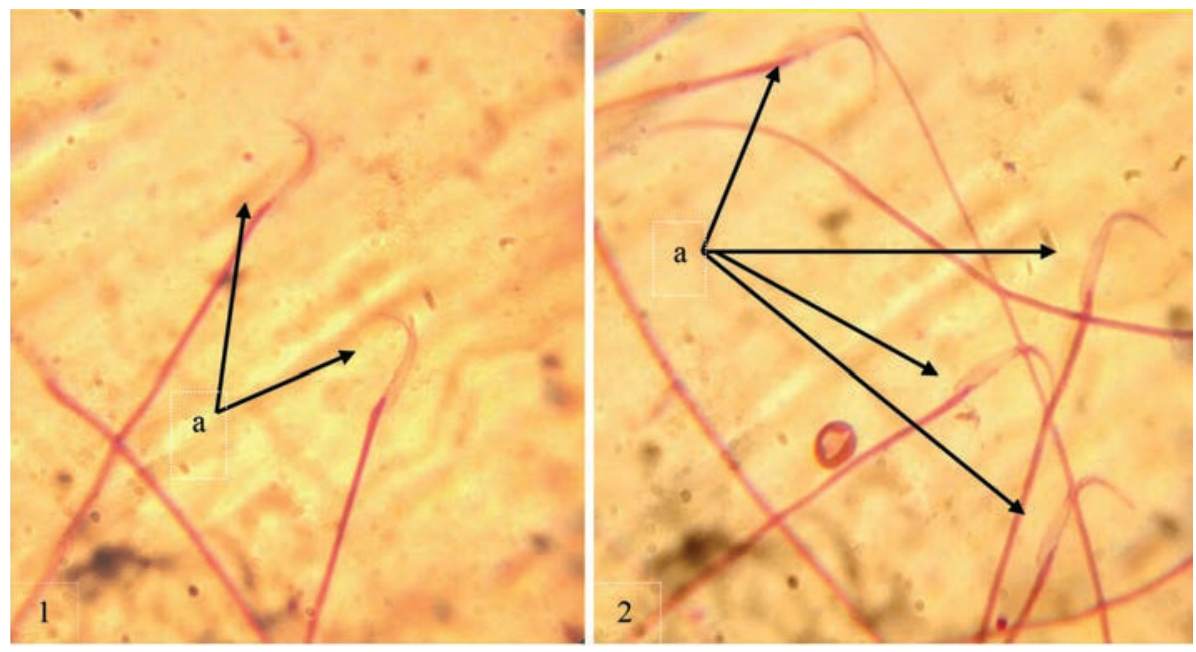

Рис. 2. Сперматозоїди самців-щурів (а): 1 - контроль; 2 - під гірудологічним впливом (об. × 100; ок. × 7, «Біолар» (Польща))

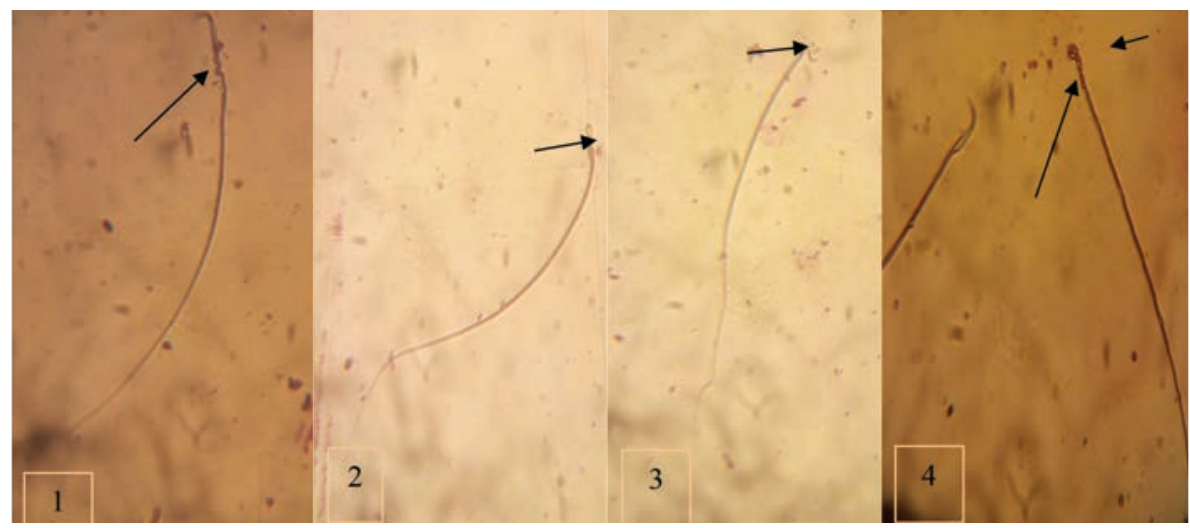

Рис. 3. Найбільш поширені морфологічні дефекти сперматозоїдів, позначені чорними стрілками: 1 - шийний дефект; 2, 3 - головний дефект; 4 - дефект голови та шийки сперматозоїда (об. × 100; ок. × 7, «Біолар» (Польща))

в більшості випадків унеможливлюють запліднення яйцеклітини ${ }^{40,41}$. Тому зменшення дефектних сперматозоїдів за рахунок гірудовпливу підвищує ймовірність запліднення.

Підвищення морфофізіологічних і репродуктивних властивостей у дослідних груп тварин має багатофакторні механізми. Насамперед це зумовлюється комплексною дією самого гірудологічного впливу. По-перше, пошкодження МП шкірного покриву годувальника генерують у нього захисні рефлекторні реакції в нейронендокринній та імунній системі. По-друге, обмежена крововтрата за рахунок годування МП та наступного незначного крововиливу з ранки приводить до мобілізації регіонарного мікроциркуляторного русла й подальшого перерозподілу кровообігу, що стимулює репараційні реакції. По-третє, і найголовніше, введення в ранку під час годування більше 100 компонентів БАР у відповідній дозі й послідовності забезпечує весь спектр гомеоста- тичного впливу на організм годувальника. 3 нього ми виділяємо для обговорення їх імунотропну дію. Так, у наших та багатьох інших дослідженнях встановлено, що саме імунітет контролює морфогенетичний структурний гомеоста3 $30,31,37-39$. Зокрема, встановлено, що БАР МП проявляють насамперед протизапальну дію, і цей механізм, як нами встановлено, здійснюється шляхом індукції локального апоптозу імунокомпетентних клітин ${ }^{42}$, тоді як на системному рівні БАР МП активують усі ланки імунної системи організму: іiї центральні (тимус і кістковий мозок), периферійні (селезінку) органи, мієлоїдні та лімфоїдні показники крові ${ }^{30,31}$. Своєю чергою стимуляція імунітету забезпечує всі морфофізіологічні прояви гірудологічного впливу, а саме фізичні показники маси тіла дослідних тварин та їх приплоду, зокрема й репродуктивні властивості тварин $^{30,31}$.

Наші експериментальні дані підтверджуються сучасними відкриттями в галузі імунології. Так, 
групою вчених було доведено провідну роль у структурному гомеостазі саме імунної системи, яка виконує морфогенетичну функцію - здійснює контроль і регуляцію метаболізму, проліферацію та диференціювання клітин усіх тканин, зокрема й імунокомпетентних ${ }^{37-39}$. Цю функцію виконує набір клонів помірно аутореактивних без цитостатичного ефекту до стадії специфічних тканинних структур Т- та В-лімфоцитів ${ }^{37-39}$. Вони здійснюють тонку регуляцію диференціювання клітин у тканинах за умови фізіологічних і репаративних регенерацій. Окрім того, в останнє десятиліття була виявлена й функціонально охарактеризована нова група імунокомпетентних клітин - вроджені лімфоїдні клітини (англ. ILC) ${ }^{43}$. Вони є відносно резидентними клітинами, інфільтрують відповідні органи та першими реагують на зміну структурного мікрооточення, а потім здійснюють цитокінову мобілізацію клітин вродженого й надалі клоноспецифічного (Т- і В-лімфоцитів) адаптивного імунітету на відтворення структурного гомеостазу, контролюючі метаболічні та морфогенетичні реакції клітин усіх тканин. Водночас клональні Т- і В-лімфоцити здійснюють тонку регуляцію диференціювання клітин у тканинах за їх фізіологічної, а також репаративної регенерації ${ }^{37-39}$.

Варто зауважити, що позитивний вплив БАР МП на самиць дослідних тварин, який представлений у попередніх наших дослідах ${ }^{29-31}$, i надалі реалізувався адекватними показниками в їх приплоду: збільшувалася кількість народжуваного приплоду, вага тіла та лімфоїдних органів. Цей факт ми також пояснюємо активацією морфогенетичної функції імунної системи. Однак, повертаючись до нашого досліду, варто зауважити, що вищезазначені позитивні ефекти впливу БАР МП мали місце й у приплоду від дослідних щурів, які народжувалися від інтактних до гірудологічного впливу самиць. Цей феномен, імовірно, зумовлений якістю еякуляту дослідних самців, що виявлений нами вперше. Однак механізм його здійснення ще потребує подальших спрямованих експериментальних досліджень. При цьому, незважаючи на таку невизначеність, наше дослідження допоможе наблизити до вирішення проблем фертильності в людей і тварин та відкриває новий напрям у вивченні статевих репродуктивних відносин.

\section{Висновки}

Гірудологічний вплив стимулює морфогенетичну функцію імунної системи самців: збільшується вага тіла та основних лімфоїних органів, а також активується репродуктивна функція, яка проявлялася у збільшенні ваги надсім'яників і загальної кількості сперматозоїдів та в паралельному зменшенні морфологічно дефектних клітин, що відіграє вирішальну роль у заплідненні. Від самців дослідної групи народжувалася більша кількість умовно здорового приплоду порівняно 3 контролем, де іноді траплявся частково мертвий приплід під час народження. Отримані результати окреслюють перспективу для подальшого вивчення репродуктивної функції після гірудологічного впливу в питанні не лише еякуляту, а й морфології репродуктивних органів тварин.

\section{Література}

(1) Потемина Т.Е.; Тукмакова Т.С. Влияние теплового воздействия на сперматогенез в эксперименте. THOSE. STM. 2011, 4, c. 99-101.

(2) Odum, J.; Creasy, D.; Cartwright, J. Guidance document for histologic evaluation of endocrine and reproductive tests in rodents. ENV/JM/MONO, 2009, 11(106), pp. 1806-1810.

(3) Оганесян, М.А., Скуратовская, Л.Н., Дроздов, Г.А. Нарушение репродуктивной функции в условиях психоэмоционального стресса. Патофизиология и современная медицина, Материалы II Междунар. конф. Москва, сентябрь 6-9, 2004.

(4) Трошин, В.Д. Стресс и стрессогенные расстройства, Медицинское информационное агентство: Москва, 2007.

(5) Потемина, Т.Е.; Кузнецова, С.В.; Ляляев, В.А. Изменение параметров семенной жидкости самцов белых крыс при различных видах экспериментального стресса. Биомедицинские исследования. 2009, 2, c. 23-26.

(6) Верещако, Г.Г.; Чуешова, Н.В.; Бакшаева, М.А.; Козлов, А.Е.; Цуканова, Е.В.; Шалатонин, В.И. Чувствительность репродуктивной системы крыс-самцов к изолированному и сочетанному действию внешнего облучения $(1,0$ Гр) и магнитного поля промышленной частоты (50 Гц). Журн. Белорус. гос. ун-та. Экология. 2017, 1, с. 46-53.

(7) Rezvanfar, M.A.; Sadrkhanlou, R.A.; Ahmadi, A. Protection of cyclophosphamide-induced toxicity in reproductive tract histology, sperm characteristics, and DNA damage by an herbal source; evidence for role of free-radical toxic stress. Human \& Experimental Toxicology. 2008, 27(12), pp. 901-910. URL: https://doi.org/10.1177/0960327108102046.

(8) O'Shaughnessy, P.J.; Morris, I.D.; Baker, P.J. Leydig cell regeneration and expression of cell signaling molecules in the germ cell-free testis. Reproduction. 2008, 135(6), pp. 851-858. URL: https://doi.org/10.1530/REP-07-0529. 
(9) Mohamed, I.E.; Nur, E.E.; Abdelrahman, M.E. The antibacterial, antiviral activities and phytochemical screening of some Sudanese medicinal plants. EurAsia J BioSci. 2010, 4(2), pp. 8-16. URL: https://doi:10.5053/ejobios.2010.4.0.

(10) Саяпина, И.Ю.; Огородникова, Т.Л. Количественная оценка функциональной активности семенников крыс на этапах адаптации к низким температурам. Научный журнал КубГАУ. 2013, 89(5), с. 1-13.

(11) Логинов, П.В.; Николаев, А.А. Коррекция сперматогенеза в условиях воздействия микроволнового излучения КВЧ-диапазона. Фундаментальные исследования. 2015, 2(14), с. 3085-3090.

(12) Власенко, Е.К.; Сычик, С.И.; Стельмах В.А.; Ильюкова, И.И.; Грынчак В.А.Особенности влияния гексилового эфира 5-аминолевулиновой кислоты на репродуктивные функции белых крыс. Becmник ВГМУ. 2015, 14(3) с. 83-89.

(13) Лебедева, С.А.; Спасов, А.А.; Бугаева, Л.И.; Смирнов, А.В.; Толокольников, В.А.; Бундикова, T.М. Влияние дефицита магния на поведенческую активность, процессы фертильности и репродуктивные органы крыс-самок. Микроэлементы в медищине. 2016, 16 (1), с. 15-21.

(14) Спасов, А.А.; Гетманенко, А.Ю.; Бугаева, Л.И.; Лебедева, С.А.; Коржова, Т.М.; Кузубова, Е.А.; Мальцев М.С. Влияние алиментарной гипомагнезиемии на процессы репродукции крыс. Волгоградский научно-медичинский журнал. 2017, 1, с. 17-21.

(15) Данкович, Н.А. Проблема бесплодия и пути ее решения. Семейная медицина. 2005, 1, с. 10-13.

(16) Лесин, А.И. Некоторые социально-физиологические причины бесплодия супружеской пары. Есть ли перспектива дальнейшего существования человечества?. Здоровье мужчиныл. 2007, с. 194-200.

(17) Louis, G.M.; Lum, K.J.; Sundaram, R. Stress reduces conception probabilities across the fertile window:evidence in support of relaxation. Fertil. Steril. 2011, 95, pp. 2184-2189. URL: https://doi. org/10.1016/j.fertnstert.2010.06.078.

(18) Паращук, Ю.С.; Каліновська, О.І.; Грищенко, М.Г.; Паращук, В.Ю. Безплідність у шлюбі : навч. посібник. ХНМУ: Харків, 2014.

(19) Мубаракшина, О.А. Особенности применения препаратов магния беременными женщинами. Фарматека. 2013, 18, с. 2-5.

(20) Толокольников В.А.; Смирнов А.В.; Спасов А.А.; Бугаёва Л.И.; Лебедева С.А.; Быхалов Л.С. Сравнительная характеристика патоморфологических изменений матки крыс при развитии дефицита магния в условиях фармакологической коррекции. Современные проблемы науки и образования. 2015, 3.

(21) Зарубина, Е.Г.; Лысова, А.Н. Роль кисспептина в нормализации эстрального цикла взрослых половозрелых самок крыс. Современные проблемы науки и образования. 2015, 2(1).

(22) Татарчук, Т.Ф.; Косей Н.В.; Регеда, С.И.; Яроцкая, Н.В.; Горохова, А.А. Гиперпролактинемия в генезе стресс-индуцированного бесплодия. Возможности фитотерапии. Здоровье женщины. 2017, 3(119), с. 28-36.

(23) Быков В.Л. Сперматогенез у мужчин в конце XX века. Проблемы репродукиии, 2000, 1, с. 6-13.

(24) Oyewopo, A.O.; Olaniyi, S.K.; Oyewopo, C.I. Radiofrequency electromagnetic radiation from cell phone causes defective testicular function in male Wistar rats. J. Repr. Endocr. \& Infertility. 2017, 2(22), pp. $1-5$.

(25) Евдокимов, В.В.; Селиванов, Т.О. Нарушение сперматогенеза при варикоцеле: патогенез и прогноз лечения. Андрология и генитальная хирургия. 2006, 3, с. 12-13.

(26) Волошин, Н.А.; Тополенко, Т.А. Морфофукциональные особенности формирования яичек крыс от момента рождения до второго месяца жизни. Украӥнський морфологічний альманах. 2009, 7(2), c. $32-34$.

(27) Cooper T.G.; Noonan E.; von Eckardstein S.; Auger J.; Baker H.W.; Behre H.M.; Haugen T.B.; Kruger T.; Wang C.; Mbizvo M.T.; Vogelsong K.M. World Health Organization reference values for human semen characteristics. Hum Reprod Update. 2010. 16(3), pp. 231-45.

(28) Iwasaki, A.; Medzhitov, R. Regulation of adaptive immunity by the innate immune system. Science. 2010, 327, pp. 291-295.

(29) Амінов, Р.Ф.; Фролов, О.К. Проліферативна активність клітин кісткового мозку щурів за впливу біологічно активних речовин медичної п'явки. Regulatory Mechanisms in Biosystems. 2017, 8 (4), c. 501-505.

(30) Aminov, R.F.; Frolov, A.K. Influence of ectoparasite - Hirudo verbana on morphogenetic reactions of the host organism - rattus. Current trends in immunology. 2017, 18 pp. 107-117.

(31) Aminov, R.F.; Frolov, A.K. The impact of fetal load of Hirudo verbana saline extract antigens morphometrical, hematological and immunological parameters of rats in the early stages of postembryonic development. Annals of parasitology, 2018, 64(1), pp. 13-20. 
(32) Фролов, А., и др. Влияние гирудотерапии на физиологические показатели у коз. Твариннищтво України. 2010, 7, с. 7-10.

(33) Лялина, Е.Г. Сочетанное применение гирудотерапии, рефлексотерапии и гомеопатии в лечении женского бесплодия. Психосоматические и интегративные исследования. 2016, 2, 0207.

(34) Амінов, Р.Ф.; Фролов, О.К.; Федотов, С.Р. (Запорізький національний університет). Пристрій для фіксації дрібних лабораторних тварин. Патент Україна 107289, травень 25, 2016.

(35) Крылова Е.В., Потемина Т.Е., Корягин А.С., Нестеров Г.Д. Профилактическое действие маточного молочка пчел на показатели сперматогенеза крыс при остром тепловом стрессе. Вестник Нижегородского университета им. Н.И. Лобачевского. 2011, 6 (1), с. 138-143.

(36) Chueshova, H.B. Comparative effects analysis short-term and long-term electromagnetic exposure mobile phone $(1800 \mathrm{MHz})$ for reproductive system male rats. Vestsi NAS Belarusi Ser. honey Navuk. 2016, 3, pp. 74-77.

(37) Бабаева, А.Г. Регенерация: факты и перспективы. РАМН: Москва, 2009.

(38) Бабаева, А.Г.; Геворкян, Н.М.; Зотиков, Е.А. Роль лимфоцитов в оперативном изменении программы развития тканей РАМН: Москва, 2009.

(39) Бабаева А.Г. Еще раз о морфогенетической, или строительной функции 200 лимфоцитов. Вестник российской академии естественных наук. 2010, 4, с. 70-74.

(40) Бичко С.В; Дунаєва О.В.; Артеменко О.Б.; Терещенко О.В. Виявлення пошкоджень сперматозоїдів птиці під час низькотемпературного консервування. Проблеми криобиологии. 2005, 15(3), c. $272-275$.

(41) Гурженко, Ю.М.; Куценко А.О. Особливості порушень сперматогенезу чоловіків із безпліддям залежно від застосованих методик допоміжних репродуктивних технологій. Семейная медицина. 2016, 5(67), с. 132-137.

(42) Амінов Р.Ф. Проліферативна активність лімфоцитів крові нелінійних самиць щурів, їх приплоду на ранніх етапах постембріонального розвитку на фоні гірудовпливу. Вісник Запорізького національного університету. Біологічні науки. 2018, 1, с. 40-45.

(43) Eric Vivier, David Artis, Marco Colonna, Andreas Diefenbach, James P Di Santo, Gérard Eberl. Innate lymphoid cells: 10 years on. Cell. 2018, 174(5): 1054-1066. 